\title{
Effect of Feeding with Organic Microelement Complex on Blood Composition and Beef Production of Young Cattle
}

\author{
Ivan Fedorovich Gorlov ${ }^{1}$, Vladimir Ivanovich Levakhin ${ }^{2}$, Vasily Fedorovich Radchikov ${ }^{3}$, Viktor Petrovich Tsai ${ }^{3}$ \\ \& Svetlana Evgenevna Bozhkova ${ }^{1}$ \\ ${ }^{1}$ The Volga region research institute of manufacture and processing of meat-and-milk production, Russian \\ Federation \\ ${ }^{2}$ Federal State Budget Scientific Institution All-Russian Research Institute of Beef Cattle, Russian Federation \\ ${ }^{3}$ Republican Unitary Enterprise"Scientific Practical Centre of Belarus National Academy of Sciences on Animal \\ Breeding", the Republik of Belarus
}

Correspondence: Ivan Fedorovich Gorlov, the Volga region research institute of manufacture and processing of meat-and-milk production, 400131, 6 Rokossovskogo Str., Volgograd, Russian Federation. Tel: 7-884-4239-1048. Fax: 88442 391142. E-mail: niimmp@mail.ru

Received: July 1, 2015

doi:10.5539/mas.v9n10p8
Accepted: July 27, 2015

Online Published: August 30, 2015

\begin{abstract}
Analysis of the feeding schemes has shown that higher nutritious diet of the calves raised up to 6 months of age can be provided by increasing the share of mineral substances of organic nature - the organic microelement complex (OMEC). The research studies have found that the OMEC has a positive impact on the feed palatability and beef production. As evidenced by morphological and biochemical composition of blood, the organic microelement complexes intervention into the mixed fodders MF-1, MF-2 and MF-3 activates metabolic processes in the body of the animals, with the total protein concentration accurately to increase by $7.7-7.8 \%$ $(\mathrm{P}<0.05)$, glucose - by 4.7-6.3\% $(\mathrm{P}<0.05)$, and the urea level to be down by $13.0-14.3 \%$. The tendency of red blood cells, hemoglobin, alkali reserve, calcium, phosphorus, magnesium, iron, zinc, copper to increase by 1.6-10.3\% has also been established. The OMEC integration into the composition of the complete fodders MF-1, MF-2 and MF-3 for young cattle increases the average daily gains by $9.5-12.3 \%(\mathrm{P}<0.05)$ depending on the age, with the feed costs for $1 \mathrm{~kg}$ of gain to be cut by $7-10 \%$. The organic microelement complex helps to reduce the gain costs by $7.0-10.9 \%$, depending on the age of the animals. Taking into account positive results of testing the premixes containing the OMEC on young cattle in a production environment, it is recommended to use the supplement studied as a component of a feedstuff in industrial complexes and specialized farms for beef production at the rate of $10 \%$ of the existing norms of trace elements in model formulations.
\end{abstract}

Keywords: diets, organic minerals, young cattle, OMEC(Organic Microelement Complex) MF(Mixed Fodder), WMR(Whole Milk Replacer), SLA(Serum Lysozyme Activity), SBA(Serum Bactericidal Activity), DM(Dry Matter), GOST(Russian State Industry Standard)

\section{Introduction}

Numerous studies have shown that only complete supplements of minerals and vitamins in the diet of animals have a high biological and economic efficiency. Acting as catalysts for many metabolic reactions in the body, the bioactive substances help to reduce the essential nutrients loss associated with the process of converting the nutrients into substances of the body and products. More efficient use of the nutrients significantly contributes to increasing of the livestock production on the same feed (Chechetkin, Golovatsky, Kaliman, et.al., 1982).

At this point, a large amount of experimental data on the content of trace elements and vitamins in feed, organs, and tissues of animals has been obtained. Minerals are found in all tissues of the living body (Czerwonka, Szterk, 2015). So, they make $0.6 \%$ of skin, $27 \%$ of the bone tissue, $1 \%$ of the muscle tissue, $0.2 \%$ of the fat tissue, $1.4 \%$ of the liver and the brain, each (Berenstein, 1958). The content of macro- and microelements in the body of animals is $4-6 \%$ of the mass, where the share of microelements is $99.6 \%$, microelements $-0.4 \%$ (Andreev, Afanasiev, 1976). Mineral substances enter the body of animals with feed and drinking water. After absorption they enter the liver, then are transferred to other organs and selectively deposited. The minerals are excreted from 
the body with the feces, urine, sweat, milk, and eggs (if it is a bird) (Bogdanov, 1990).

In recent years, scientists and people on the ground are increasingly focusing on the balance of feed rations, providing the animals with zinc, copper, manganese, iron, cobalt, iodine, selenium, and other nutrients (Gorlov, et. al., 2014; Blanco, Casasús, et. al., 2010; Sami., Augustini , Schwarz, 2004).

The Republic of Belarus is a biogeochemical province with a low content of these trace elements in the soil (Slavetsky, Pakhomov, Razumovsky, 2003). This fact makes it necessary to develop and to implement micronutrient supplements to the diet of animals in organic and inorganic forms.

In our opinion, the intervention of organic microelements to the diet of animals is very relevant, in-demand, and more effective, as compared to the inorganic trace elements. The organic microelement complex (OMEC) is an organic compound complex of elements for modern formulations of premixes and complex feed that stimulates the body's immune defense against viruses and other pathogenic invaders. The complex is a potent carcinostatic agent having a wide range of effects on the body of an animal, and as a consequence, on the human health.

The OMEC contains organic chelated trace elements (iron $(\mathrm{Fe})$, manganese $(\mathrm{Mn})$, zinc $(\mathrm{Zn})$, copper $(\mathrm{Cu})$, cobalt (Co), optionally with addition of iodine (J) and selenium (Se)) as L-aspartates or without them. The minimum content of trace elements in $1 \mathrm{~kg}$ of the feed supplements OMEC includes iron $-108 \mathrm{~g}$, manganese $-105 \mathrm{~g}$, zinc $-118 \mathrm{~g}$, copper $-115 \mathrm{~g}$, cobalt $-110 \mathrm{~g}$.

The purpose of the research was to study the efficiency of the OMEC as component of the complex fodders MF-1, MF-2, and MF-3 for young beef cattle.

The research had the objectives to:

- study the effect of the organic microelement complex on the feed palatability, the morphological and biochemical composition of blood, the level of natural resistance, the mineral composition of blood;

- determine the influence of the supplement on the energy growth of the young cattle;

- give zootechnical and economic assessment of the feasibility of the organic microelement complex for growing young beef cattle.

\section{Method}

To implement the goal, clinically healthy young cattle was selected in view of its body weight, age, fatness, and identical growth rate of the calves (10 animals in each experimental group) in the state owned enterprise "ZhodinoAgroPlemElita" in Smolevichski rayon of the Minsk region, the Republic of Belarus.

In the first scientific and economic experiment, the calves in control group I were fed with MF-1 with a premix of standard formulation, milk, whole milk replacer (WMR), hay, haylage, rolled corn grain. The calves in control group I were fed with the complex feed MF-1 with premix containing the OMEC feed supplement in addition to the standard diet. The experiment lasted 65 days. The calves weighing 41.9-42.5 $\mathrm{kg}$ (10-75 days of age) were selected for the studies.

In the second scientific and economic experiment, the basic diet of the calves (control group II) contained the MF-2 feed, hay, haylage, whole milk, WMR. The difference in feeding was that the youngsters in experimental group II had intervention of the premixes with the OMEK feed supplement in the complex feed MF-2. The experiment on the calves lasted 62 days, starting from the age of 3 months and initial body weight of 89.1-89.8 $\mathrm{kg}$.

The third scientific and economic experiment was conducted on the diet, which included the compound feed MF-3, green mass of grass-legume mixture, and mixed herbs haylage (control group III). The difference was in feeding the youngsters in experimental group III with the OMEC as a component of the complex feed. Duration of the experiment was 94 days, with the initial live weight of the calves at 5 months of age to be $175.0-176.0 \mathrm{~kg}$.

The housing conditions for the control and experimental groups were the same: twice-a-day feeding, watering from autodrinkers.

The calves were kept in strawed cages with outdoor run for each cage.

The sampling of feed was carried out according to GOST 27262-87. The chemical analysis of the feed was conducted in the laboratory of biochemical analyzes of the Republican Unitary Enterprise "Scientific Practical Center of Belarus National Academy of Science for Animal Breeding" according to the general zootechnical scheme of analysis: primary, hygroscopic, and total moisture (GOST 13496.3-92); total nitrogen and crude protein (GOST 13496.4-93; GOST 28075-89); crude fiber (GOST 13496.2-91); crude fat (GOST 13496.15-97); soluble and easy hydrolysable carbohydrates (sugars) (GOST 26176-91); calcium, phosphorus (GOST 26570-95; 
26657-97); dry and organic substance, nitrogen-free extractive substances (Malchevskaya, Milenkaya, 1981; Petukhova, et al., 1989).

Scientific and economic experiments were conducted by the Ovsyannikova's procedure (Ovsyannikov, 1976).

The following indicators were examined in the experiments: palatability of feed in the ration - by the accounting method of prescribed feed and its orts, by conducting the feeding check for two days once in ten days; body weight and average daily gains of the calves - by individual weighing the animals at the beginning, the middle, and the end of the experiment; morphological and biochemical composition of blood of the calves: red blood cells, white blood cells, hemoglobin - on the instrument Medonic CA 620 (Ireland); macro- and microelements in blood (potassium, sodium, magnesium, iron, zinc, manganese, copper, cobalt) - on the atomic absorption spectrophotometer AAS-3 (manufactured by Carl Zeiss Jeiss JENA, Germany); biochemical composition of blood serum: total protein, albumin, globulin, urea, glucose, calcium, phosphorus - on the analyzer Cormay Lumen (Poland); the state of natural resistance was determined by the tests characterizing the humoral protection factors: serum lysozyme activity (SLA), serum bactericidal activity (SBA) - by the photocolorimetric method (Kondrakhin, 2004; Harvey, 2012).

The economic efficiency of the young cattle breeding was calculated in accordance with the methodology of determining the economic efficiency of research and design work results, new facilities, inventions, and innovations in agriculture (The Ministry of Agriculture of the Russian Federation, 2008).

Digital data of the research was processed by methods of variation statistics on a PC using the software «Statistika 10.0», the software package "Microsoft Office 2007", and the assessment of the difference validity to Student-Fisher. The value of the reliability criterion was assessed, taking into account the volume of the material to be analyzed. The reliability of the differences was considered to be significant at a significance level of $\mathrm{P}<0.05$ (Plokhinsky, 1969; Steel, Torrie and Dinkey, 1996).

\section{Results}

In the first scientific and economic experiment, the average daily diet of the test young cattle grown for 10-75 days mainly consisted of milk food added by hay and complex feed in all groups (Table 1).

Table 1 . The average daily ration of feed actually eaten

\begin{tabular}{lllll}
\hline Components and nutrients & \multicolumn{2}{c}{ Control group I } & \multicolumn{2}{l}{ Experimental group I } \\
\cline { 2 - 5 } & $\mathrm{kg}$ & Nutrition, \% & $\mathrm{kg}$ & Nutrition, \% \\
Whole milk & 3.83 & 51.8 & 3.84 & 51.2 \\
WMR & 2.04 & 18.4 & 2.06 & 18.4 \\
Complete feed MF-1 & 0.71 & 22.2 & 0.71 & 22.1 \\
Dredge corn & 0.08 & 3.5 & 0.08 & 3.6 \\
Hay & 0.20 & 3.9 & 0.23 & 4.4 \\
Haylage & 0.07 & 0.2 & 0.11 & 0.3 \\
\hline
\end{tabular}

Changes in the composition of blood in the ontogenesis process were caused by the changes in the type of feeding, housing, and physiological state. The study of morphological parameters of blood is of great importance in dealing with the impact of the nutritional factor (Table 2).

Table 2. Morphological and biochemical composition of blood of experimental animals $(n=3, M \pm m)$

\begin{tabular}{lcl}
\hline Indices & Control group I & Experimental group I \\
\hline Hemoglobin, g/l & $114.7 \pm 0.9$ & $118.3 \pm 0.8^{*}$ \\
Erythrocytes, $10^{12} / 1$ & $7.89 \pm 0.06$ & $7.95 \pm 0.02$ \\
Leukocytes, $10^{9} / 1$ & $9.55 \pm 0.27$ & $9.64 \pm 0.13$ \\
Total protein, g/l & $63.03 \pm 0.57$ & $65.77 \pm 0.14^{* *}$ \\
Albumins, g/1 & $26.28 \pm 1.15$ & $27.18 \pm 1.88$ \\
Globulins, g/1 & $36.75 \pm 0.57$ & $38.58 \pm 1.85$ \\
Glucose, $\mathrm{mmol} / 1$ & $3.27 \pm 0.12$ & $3.33 \pm 0.14$ \\
Calcium, $\mathrm{mmol} / 1$ & $2.97 \pm 0.01$ & $3.01 \pm 0.10$ \\
Phosphorus, $\mathrm{mmol} / 1$ & $2.09 \pm 0.09$ & $2.13 \pm 0.06$ \\
Iron, mmol/1 & $19.0 \pm 1.46$ & $21.0 \pm 0.72$ \\
\hline
\end{tabular}




\begin{tabular}{lcl}
\hline Magnesium, mmol/l & $2.00 \pm 0.24$ & $2.27 \pm 0.01$ \\
Cobalt, mcmol/1 & $0.56 \pm 0.03$ & $0.77 \pm 0.02$ \\
Manganese, mcmol/1 & $3.06 \pm 0.42$ & $3.72 \pm 0.04$ \\
SBA, \% & $65.12 \pm 0.88$ & $66.63 \pm 0.21$ \\
SLA, \% & $6.23 \pm 0.18$ & $6.33 \pm 0.03$ \\
\hline
\end{tabular}

Note. From this point on: $* \mathrm{P}<0.05 ; * *-\mathrm{P}<0.01 ; * * *-\mathrm{P}<0.001$ is the reliability of difference compared with the control group.

Our research studies have found a positive effect of the premixes containing inorganic salts of elements and a premix where these salts are replaced with organic forms of the elements of iron, manganese, copper, cobalt, and zinc as components of the complex feed MF-1 for the calves during their growing from 10 to 75 days of age (Table 3).

Table 3. Body weight, feed efficiency and costs $(n=10, M \pm m)$

\begin{tabular}{lll}
\hline \multicolumn{1}{c}{ Indices } & Control group I & Experimental group I \\
\hline Live weight at the start of experiment, $\mathrm{kg}$ & $42.5 \pm 0.6$ & $41.9 \pm 0.64$ \\
Live weight at the end of experiment, $\mathrm{kg}$ & $86.3 \pm 1.05$ & $91.1 \pm 1.36^{*}$ \\
Average daily gain, g & $674 \pm 21.85$ & $757 \pm 18.46^{* *}$ \\
Average daily gain increase, g & - & 83 \\
Average daily gain increase, \% & - & 12.3 \\
Additional gain increase of one animal in course of experiment, $\mathrm{kg}$ & \\
Feed costs for 1 kg of gain, fodder units & - & 5.4 \\
Feed costs cutting, fodder units & 4.29 & 3.86 \\
$\%$ & - & 0.43 \\
\hline
\end{tabular}

In the second scientific and economic experiment, feeding the animals was carried out according to the ration conventional at the farm. The results showed (Table 4) that the young stock in the experimental group fed with the OMEC as a part of complex feed was noted for a trend to an increase in nutrient intake.

Table 4. Average daily ration of feed actually eaten

\begin{tabular}{lcc}
\hline Components and nutrients & Control group II & Experimental group II \\
\hline Complete feed MF-2, kg & 1.6 & 1.6 \\
Hay, kg & 0.8 & 0.95 \\
Haylage, kg & 3.0 & 3.2 \\
Milk, 1 & 2.0 & 2.0 \\
WMR, kg & 0.4 & 0.4 \\
\hline
\end{tabular}

To study the effect of the feed supplement OMEC on the physiological state of the animals, the biochemical blood parameters were analyzed. The hematologic parameters obtained in the scientific and business experiment are given in Table 5 .

Table 5. Morpho-biochemical composition of blood of experimental animals ( $\mathrm{n}=3, \mathrm{M} \pm \mathrm{m}$ )

\begin{tabular}{lcc}
\hline Indices & Control group II & Experimental group II \\
\hline Hemoglobin, g/l & $96.5 \pm 0.82$ & $98.2 \pm 0.46$ \\
Erythrocytes, $10^{12} / 1$ & $6.97 \pm 0.32$ & $7.13 \pm 0.19$ \\
Leukocytes, $10^{9} / 1$ & $9.57 \pm 0.25$ & $9.60 \pm 0.23$ \\
Total protein, g/l & $72.44 \pm 1.18$ & $78.0 \pm 0.87^{*}$ \\
Glucose, $\mathrm{mmol} / \mathrm{l}$ & $3.2 \pm 0.2$ & $3.4 \pm 0.2$ \\
Calcium, $\mathrm{mmol} / 1$ & $3.75 \pm 0.07$ & $4.01 \pm 0.09$ \\
Phosphorus, $\mathrm{mmol} / 1$ & $2.62 \pm 0.04$ & $2.77 \pm 0.06$ \\
Magnesium, mmol/1 & $1.24 \pm 0.02$ & $1.26 \pm 0.02$ \\
\hline
\end{tabular}




\begin{tabular}{lcc}
\hline Iron, $\mathrm{mmol} / \mathrm{l}$ & $18.7 \pm 0.89$ & $20.3 \pm 0.86$ \\
Potassium, mmol/1 & $9.9 \pm 0.04$ & $10.4 \pm 0.4$ \\
Natrium, mmol/1 & $110.5 \pm 2.8$ & $111.2 \pm 3.3$ \\
Zink, mcmol/1 & $4.6 \pm 3.3$ & $4.8 \pm 1.8$ \\
Manganese, mcmol/1 & $1.7 \pm 0.1$ & $1.5 \pm 0.2$ \\
Copper, $\mathrm{mcmol} / 1$ & $12.1 \pm 0.79$ & $13.3 \pm 0.49$ \\
SBA, \% & $63.1 \pm 1.0$ & $64.9 \pm 1.5$ \\
SLA, \% & $6.3 \pm 0.29$ & $6.5 \pm 0.35$ \\
\hline
\end{tabular}

The intervention of the feed supplement OMEC directly influenced the average daily gain of the calves (Table $6)$.

Table 6. Body weight and average daily gains of calves ( $\mathrm{n}=10, \mathrm{M} \pm \mathrm{m})$

\begin{tabular}{lll}
\hline Indices & Control group II & Experimental group II \\
\hline Live weight at the start of experiment, $\mathrm{kg}$ & $89.8 \pm 3.59$ & $89.1 \pm 3.07$ \\
$\begin{array}{l}\text { Live weight at the end of experiment, } \mathrm{kg} \\
\text { Average gain: }\end{array}$ & $140.8 \pm 2.18$ & $145.2 \pm 3.12$ \\
gross, kg & & \\
daily, g & $51.0 \pm 1.73$ & $56.1 \pm 2.39$ \\
\%, compared with control & $823 \pm 6.2$ & $905 \pm 6.7 * * *$ \\
\hline
\end{tabular}

The study of the feed palatability in the third scientific and economic experiment showed that the inclusion of the OMEC into the fodder MF-3 had a positive effect on the feed intake (Table 7).

Table 7. Average daily ration of feed actually eaten

\begin{tabular}{lcc}
\hline Components and nutrients & Control group III & Experimental group III \\
\hline Complete feed MF-3, kg & 2.5 & 2.5 \\
Legume-grass mixture herbage, kg & 6.0 & 6.4 \\
Mixed herbs haylage, kg & 6.0 & 6.2 \\
\hline
\end{tabular}

The indicators of morphological and biochemical composition of blood and etc. in the third scientific and business experiment were within the physiological norm (Table 8).

Table 8. Morpho-biochemical composition of blood of the experimental animals ( $\mathrm{n}=3, \mathrm{M} \pm \mathrm{m}$ )

\begin{tabular}{lll}
\hline Indices & Control group III & Experimental group III \\
\hline Hemoglobin, g/l & $90.1 \pm 0.8$ & $92.4 \pm 0.5$ \\
Erythrocytes, $10^{12} / 1$ & $7.9 \pm 0.4$ & $8.3 \pm 0.3$ \\
Leukocytes, $10^{9} / 1$ & $8.4 \pm 0.25$ & $8.6 \pm 0.4$ \\
Total protein, g/l & $70.4 \pm 1.1$ & $75.9 \pm 1.3^{*}$ \\
Glucose, mmol/1 & $71.4 \pm 0.4$ & $74.8 \pm 0.6^{* *}$ \\
Calcium, mmol/1 & $2.9 \pm 0.4$ & $3.2 \pm 0.1$ \\
Phosphorus, $\mathrm{mmol} / 1$ & $1.4 \pm 0.2$ & $1.6 \pm 0.2$ \\
Magnesium, mmol/1 & $1.1 \pm 0.1$ & $1.2 \pm 0.15$ \\
Iron, mmol/1 & $17.4 \pm 0.4$ & $19.2 \pm 0.6$ \\
Potassium, mmol/1 & $5.6 \pm 0.5$ & $5.7 \pm 0.6$ \\
Natrium, mmol/1 & $104.5 \pm 2.4$ & $106.6 \pm 2.7$ \\
Zink, mcmol/1 & $29.4 \pm 0.8$ & $31.2 \pm 0.9$ \\
Manganese, $\mathrm{mcmol} / 1$ & $2.0 \pm 0.3$ & $2.2 \pm 0.6$ \\
Copper, mcmol/1 & $11.9 \pm 1.2$ & $12.8 \pm 1.4$ \\
SBA, \% & $65.2 \pm 1.5$ & $70.1 \pm 2.0$ \\
SLA, \% & $6.1 \pm 0.24$ & $6.8 \pm 0.30$ \\
\hline
\end{tabular}


The OMEC as a component of the combined fodder MF-3 has had a positive effect on the body weight and the average daily weight gains of the young cattle (Table 9).

Table 9. Body weight and average daily gains of calves $(n=10, M \pm m)$

\begin{tabular}{lll}
\hline Indices & Control group III & Experimental group III \\
\hline Live weight at the start of experiment, $\mathrm{kg}$ & $175.0 \pm 6.5$ & $176.0 \pm 5.5$ \\
Live weight at the end of experiment, $\mathrm{kg}$ & $252.8 \pm 5.9$ & $261.3 \pm 7.1$ \\
Average gain: & & \\
$\quad$ gross, $\mathrm{kg}$ & $77.8 \pm 6.1$ & $85.3 \pm 4.8$ \\
$\quad$ daily, g & $828 \pm 5.0$ & $907 \pm 6.1^{*}$ \\
$\%$, compared with control & 100.0 & 109.5 \\
\hline
\end{tabular}

\section{Discussion}

The experimental animals consumed $1.71-1.75 \mathrm{~kg}$ of dry matter a day, the metabolic energy concentration in the dry matter (DM) was $14.6 \mathrm{MJ}$ in the diet of experimental group I and 14.7 - in the diet of control group I. The share of crude protein was $24.5 \%$ of DM in the diet of control group I and $24.3 \%$ - in experimental group I. 14.1 grams of digestible protein is accounted for by $1 \mathrm{MJ}$ of metabolic energy of the diet in control and experimental groups I. Concentration of digestible carbohydrates (starch and sugar) was 33.5\% of the DM in the diet of control group I, and 32.9\% - of experimental group I. The ratio of calcium and phosphorus was 1.3:1 in the diet of control group I and 1.31:1 - in experimental group I.

The results showed that the blood of 75-days old calves in test group I contained more red blood cells by $0.8 \%$, compared with control group I. The concentration of iron-containing globular protein was registered to exceed the same parameter in the control group by $3.6 \mathrm{~g} / 1$.

The young stock in test group I had higher saturation of red blood cells with the respiratory pigment hemoglobin by $3.1 \%(\mathrm{P}<0.05)$ than the animals fed with a standard premix that indicates the metabolism intensity.

Comparative analysis of the experimental data showed that the intensively growing individuals have higher rates of oxidative properties of blood and, conversely, the reduced growth rate was accompanied by a decrease in the hemoglobin concentration.

The diets with the premix studied had a stimulating effect on the concentration of white blood cells - it increased by $0.9 \%$, which is probably due to the high level of protective properties of organism.

The studies found that the replacement of inorganic chemical compounds in the premix with organic forms relative to the reference value caused increase in the total protein content by $4.3 \%(\mathrm{P}<0.01)$. Increase in the total protein content in the blood serum of animals indicates better digestibility of protein and of valuable protein of microorganisms inhabiting the rumen.

The albumins increase in blood is presumably linked with the enhanced proteins activity and their exchange that is typical for growing animals. In blood of the calves in experimental group I, the albumin level increased by $3.4 \%$, compared to control group I.

Ratio Albumins/Globulins determines the physical and chemical activity of the blood and to a large extent the nature and the intensity of metabolism in the body. The animals in control and experimental groups I were established to have the protein ratio of 0.7-0.71 units.

The glucose content in the blood serum is in direct proportion to the energy content of the diet, as well as to the balance with other nutrients that affect the metabolic processes in the body. So, the glucose concentration in test group I increased by $1.8 \%$ relative to control group I that confirm minor differences in energy concentration of the rations.

The content of macro- and micronutrients in blood, including calcium, phosphorus, iron, etc. is of great value for determining the physiological state of animals.

So, the calcium level in the blood serum increased by $1.3 \%$, with the calves to be fed a diet with chelate compounds of minerals as components of the premixes. The blood serum of the animals in experimental group I was notable for enhanced content of inorganic phosphorus by $1.9 \%$, compared with the control I. Significant differences between the groups according to the elements were not found.

Iron is necessary for the synthesis of hemoglobin, which holds more than half of its reserves in the body. As an 
oxygen carrier, iron enhances the exchange of nutrients within the cell. In blood of the calves in experimental group I, the iron content exceeded the control by $10.5 \%$.

Taking into account all the differences of blood parameters between the groups, it has been found that they were within the physiological norm and indicate the normal course of metabolic processes.

Thus, the morphological and biochemical indices of blood in growing calves confirm their relationship to the level and quality of mineral nutrition, providing the conditions for the animals' growth, development, and level of productivity.

An important factor responsible for the formation of beef production of young cattle in ontogenesis is the level and the quality of mineral nutrition, which contributes to the development of lean tissue in the body particularly at an early age (Gorlov, et. al., 2012; Popov, Sirazetdinov, et. al., 2011). The basis of the feeding involves increasing the feed efficiency due to the maximum dose of nutrients and mineral elements of the diet that increase the beef production of the animals.

The highest productivity was registered in test group I since the animals aged 75 days exceeded the control by $12.3 \%$.

The growth intensity is one of the main features that characterizes the livestock productivity; the calves in experimental group I have the highest rate.

One of the indicators of rational use of feed is the feed cost per unit of live weight gain. Feeding the calves with premixes containing chelate compounds of minerals contributed to a higher efficiency of the feed to increase the growth. The comparative analysis clearly showed that the animals of the experimental group I more effectively digested the feed, which had lower costs than the feed in the control group by $10.1 \%$. The cost calculation found that increasing the weight gain of the calves caused the cost reduction by $10.9 \%$, with little difference in the feed cost.

In the second scientific and economic experiment, $160 \mathrm{~g}$ of crude protein were calculated per one feed unit; the metabolic energy concentration in $1 \mathrm{~kg}$ of DM in the diet was 10.2-10.3MJ. The fiber content was within $17.6-18.0 \%$ at the rate of $16 \%$ of the DM intake. The sugar-protein ratio was $0.76: 1$. The ratio of calcium to phosphorus was 1.72-1.76:1.

The studies found that the OMEC intervention into the diet of the experimental animals has no adverse affect on the basic morphological and biochemical parameters of blood that were within the physiological norms.

According to our data obtained, the number of erythrocytes in blood of the calves in test group II was higher than in the control group by $2.3 \%$. The increase of total protein in serum of the experimental analogues was registered by $7.7 \%(\mathrm{P}<0.05)$, the reduction in the urea concentration - by $13.0 \%$.

The data on the impact of the feed supplement OMEC as a component of the complex feed MF-2 on the natural resistance (Table 5) show that the SBA and the SLA in blood of the calves in experimental group II were higher by 2.9 and $3.2 \%$, respectively after starting the intervention of the feed supplement, two months later. The mineral composition of blood of the calves fully demonstrates the impact of the new feed supplement on the change in metabolism of macro- and trace elements (Table 5).

The intervention of the feed supplement OMEC into the diet of young cattle had a positive effect on the iron metabolism. The concentration of this trace element in experimental group II was higher by $8.6 \%$ than in control group II.

The calcium content in blood of the experimental calves was higher by $6.9 \%$, phosphorus - by $5.7 \%$, magnesium - by $1.6 \%$, compared with the target values.

The research results at the end of the experiment after the fodder supplement intervention indicate that the young animals in experimental group II had the maximum increase in the average daily gain that is above the target values by $10 \%(\mathrm{P}<0.001)$ (Table 6$)$.

The analysis of the experimental data obtained showed that the feed cost per $1 \mathrm{~kg}$ of gain declined by $7.0 \%$ after starting the intervention of a premix with the feed supplement OMEC into the diet of the calves in experimental group II. The cost price of $1 \mathrm{~kg}$ of gain was down by $7.2 \%$.

The study of the feed palatability in the third scientific and economic experiment showed that according to their nutrition, the fodders occupied $47-49 \%$ in the structure of the rations, the legume-grass mixture herbage $20-23 \%$, mixed herbs haylage $-30-31 \%$. The content of metabolic energy per $1 \mathrm{~kg}$ of DM in the diet was $8.0 \mathrm{MJ}$ in the control group, and $8.4 \mathrm{MJ}$ in the test one. 
Thus, $110 \mathrm{~g}$ of digestible protein were calculated per one feed unit in control group III and $111 \mathrm{~g}$ in experimental group III. The content of feed units per $1 \mathrm{~kg}$ of DM in the diet was 0.9 feed units in control group III and 1.0 feed unit in experimental group III, of crude protein - 160 and 161, respectively. The fiber concentration in DM of the diet was $21.0 \%$ in control group III, and $20.7 \%$ in test group III. The content of starch+sugar in DM of the diet was $23 \%$ in control group III and $22.8 \%$ in experimental group III. The amount of starch+sugar relative to the crude protein in the diet of young stock of both groups was 1.4. The ratio of starch to sugar was 1.4:1, protein to sugar - 0.88-0.90:1, calcium to phosphorus - 1.5-1.6:1 that corresponds to the norms (Kholod, Kurdeko, 2005).

It has been found that the total protein level in blood of the calves in experimental group III was higher by $7.8 \%$ $(\mathrm{P}<0.05)$, glucose - by $4.7 \%(\mathrm{P}<0.01)$, and urea - by $14.3 \%$, compared with control group III (Table 8$)$.

The data presented show that feeding the young cattle in experimental group III with the feed supplement OMEC as a component of the fodder MF-3 helped to increase the lysozyme activity by $0.7 \%$, the bactericidal activity by $4.9 \%$, compared with control group III.

The fodder MF-3 with the organic microelement complex (experimental group III) had a positive impact on the mineral content of blood. The tendency to increase the calcium level by $10.3 \%$, phosphorus - by $14.0 \%$, magnesium - by $9.0 \%$, iron - by $10.3 \%$ has been found.

The research studies found that the average daily gains of the calves in experimental group III increased by $9.5 \%$.

As evidenced by the data of the economic efficiency, the feed cost per $1 \mathrm{~kg}$ of gain per head was reduced by $9 \%$ and the feed consumption - by $6.5 \%$, with the young cattle to be fed with the OMEC premix as a component of the complex feed MF-3 (experimental group III). The gross gain cost per head increased by $1.2 \%$.

However, the production cost decreased by $7 \%$ because of higher gross weight gain in the experimental group of the calves $(85.3 \mathrm{~kg}$ vs. $77.8 \mathrm{~kg})$.

\section{Conclusion}

An innovative product of new generation, the OMEC is a mixture of salts of iron, cobalt, zinc, copper, and manganese (with or without iodine, selenium) as aspartates. Application of the OMEC significantly increases the digestibility of the elements, important for the normal functioning of the body. This form of trace elements can significantly increase the bioavailability of nutrients. This form helped to reduce the initial amount of mineral salts used that is fundamentally different from the conventional feed supplements. Recent data show that the trace elements optimization of feeding intensifies the production of high quality meat.

The OMEC as a component of the combined fodders MF-1, MF-2, and MF-3 at the rate of $10 \%$ of the existing norms of trace elements in a typical formulation for growing young beef cattle has a positive impact on the palatability of the feed, the morphological and biochemical composition of blood, and productivity of the animals.

The organic microelement complex helps to cut the cost of gain by $7.0-10.9 \%$, depending on the age of the young stock.

\section{Acknowledgments}

The authors are grateful to the Russian Science Foundation for the financial support in the implementation of this research according to the scientific project \# 15-16-10000, NIIMMP.

\section{References}

Andreev, N. G., \& Afanasiev, R. A. (1976). Efficiency of micronutrients. Dairy cattle on cultivated grassland. Moscow: Rosselkhozizdat, Russian Federation. pp. 34-38.

Berenstein, F.Ya. (1958). Trace elements, their biological role and significance for livestock. Minsk: Uradzhay, The Republic of Belarus.

Blanco, M., Casasús, I., Ripoll, G., Panea, B., Albertí, P., \& Joy, M. (2010). Lucerne grazing compared with concentrate-feeding slightly modifies carcase and meat quality of young bulls. Meat Science, 84(3), 545-552. (Abstr.). http://dx.doi.org/10.1016/j.meatsci.2009.10.010

Bogdanov, G. A. (1990). Animal Nutrition (2nd Ed). revised. and add. Moscow: Agropromizdat, Russian Federation.

Chechetkin, A. V., Golovatsky I. D., Kaliman, P. A., \& Voronianskij, V. I. (1982). Biochemistry of animals: 
course book for agricultural Universities. Moscow: Higher School, Russian Federation.

Czerwonka, M., \& Szterk, A. (2015). The effect of meat cuts and thermal processing on selected mineral concentration in beef from Holstein-Friesian bulls. Meat Science, 105, 75-80 (Abstr.). http://dx.doi.org/10.1016/j.meatsci.2015.03.011

Gorlov, I. F. (2012). New approaches to the use of dietary supplements and growth-stimulating agents in beef production: monograph. The Ministry of Agriculture of the Russian Federation, Department of Science and Technology Policy and Education, VPO Volgograd State Agricultural Univ., Volgograd, Russian Federation.

Gorlov, I. F., Mosolova, N. I., Zlobina, E. Yu., Korotkova, A. A., \& Prom, N. A. (2014). Use of New Supplement Feeds Based on Organic Iodine in Rations of Lactating Cows. American-Eurasian Journal of Agricultural \& Environmental Sciences, 14(5), 401-406.

Harvey, J. W. (2012). Veterinary Hematology. A diagnostic guide and color atlas. Elsevier Saunders.

Kholod, V. M., \& Kurdeko, A. P. (2005). Clinical biochemistry. Part 1. Vitebsk, The Republic of Belarus.

Kondrakhin, I. P. (2004). Methods of veterinary clinical laboratory diagnostics: Reference book. Moscow: Kolos, Russian Federation.

Malchevskaya, E. N., \& Milenkaya, G. S. (1981). Quality assessment and analysis of zootechnical feed. Minsk: Uradzhay, The Republic of Belarus.

Ovsyannikov, A. I. (1976). Basis of experimental work in livestock. Moscow: Kolos, Russian Federation.

Petukhova, E. A., Bessabarova, R. F., \& Kholeneva, L. D. (1989). Zoo technical analysis of feed. Moscow: Agropromizdat, Russian Federation.

Plokhinsky, N. A. (1969). Guide on biometrics for livestock specialists. Moscow: Kolos, Russian Federation.

Popov, V. V., Sirazetdinov, F. Kh., Kalashnikov, V. V., Gorlov, I. F., \& Azhmuldinov, E. A. (2011). New techniques for highly efficient beef production: monograph. All-Russian Research Institute of Agricultural Sciences of beef cattle, Bashkir Institute of retraining and advanced training of AIC. Moscow, Russian Federation.

Sami, A. S., Augustini, C., \& Schwarz, F. J. (2004). Effects of feeding intensity and time on feed on performance, carcass characteristics and meat quality of Simmental bulls. Meat Science, 67(2), 195-201. (Abstr.). http://dx.doi.org/10.1016/j.meatsci.2003.10.006.

Slavetsky, V. B., Pakhomov, I. Ya., \& Razumovsky, N. P. (2003). Recommendations for of breeding healthy calves in the dairy season. Ministry of Agriculture and Food of the Republic of Belarus, the Committee on Agriculture and Food of the Vitebsk Region, Executive Committee. Vitebsk, The Republic of Belarus.

Steel, R. G. D., Torrie, J. H., \& Dinkey, D. A. (1996). Principles and Procedures of Statistics (2nd Ed.), McGraw Hill Book Co, Singapore.

The Ministry of Agriculture of the Russian Federation. (2008). Technique (fundamental principles) of the definition of economic efficiency in the national economy of new technology, inventions and innovations (Approved by Resolution of the SCS \& T Soviet Gosplan, the Academy of Sciences of the USSR, the USSR State Committee of 14.02.1977 N 48/16/13/3; as at 7 October 2006).

\section{Copyrights}

Copyright for this article is retained by the author(s), with first publication rights granted to the journal.

This is an open-access article distributed under the terms and conditions of the Creative Commons Attribution license (http://creativecommons.org/licenses/by/3.0/). 